УДК 343.53:366.54

DOI https://doi.org/10.32837/apdp.v0i83.136

T. A. Сокур

\title{
ІСТОРІЯ РОЗВИТКУ КРИМІНАЛЬНОЇ ВІДПОВІДАЛЬНОСТІ ЗА УМИСНЕ ВВЕДЕННЯ В ОБІГ НА РИНКУ УКРАЇНИ (ВИПУСК НА РИНОК УКРАЇНИ) НЕБЕЗПЕЧНОЇ ПРОДУКЦІї У ВІТЧИЗНЯНОМУ КРИМІНАЛЬНОМУ ЗАКОНОДАВСТВІ 1927-1960 РОКІВ
}

Постановка проблеми. Проблема історії розвитку кримінальної відповідальності за умисне введення в обіг на ринку України (випуск на ринок України) небезпечної продукції у вітчизняному кримінальному законодавстві має велике теоретичне та практичне значення, оскільки це дозволяє скласти найбільш повне уявлення про цей злочин. Вирішення цієї проблеми надає змогу глибше зрозуміти правову природу цього суспільно небезпечного діяння, його ознаки, з'ясувати основні тенденції його розвитку, здійснити порівняльний аналіз і зробити певні висновки щодо можливого негативного або позитивного досвіду для запозичення останнього у чинний КК.

Аналіз останніх досліджень і публікацій. Окремі аспекти історії розвитку цього злочину досліджували А.А. Герцензон, Ш.С. Грінгауз, Н.Д. Дурманов, М.М. Ісаєв [1], О.М. Готін [2, с. 15-23], П.П. Михайленко [3], В.Я. Тацій [4, с. 5-9], І.Я. Терлюк [5] та інші вчені. Водночас маловивчені положення вітчизняного кримінального законодавства 1927-1960 р.р., які передбачали відповідальність за умисне введення в обіг на ринку України (випуск на ринок України) небезпечної продукції.

Метою статті є здійснення історично-правового дослідження розвитку кримінальної відповідальності за умисне введення в обіг на ринку України (випуск на ринок України) небезпечної продукції у вітчизняному кримінальному законодавстві 1927-1960 p.p.

Виклад основного матеріалу дослідження. 31 жовтня 1924 р. були затверджені «Основні начала кримінального законодавства Союзу РСР і союзних республік», акт, що доповнював Загальну частину. Це був загальносоюзний кримінальний закон, але принципових змін до політики в галузі кримінального права він не вніс.

Суттеві доповнення до кримінального законодавства вносилися після ухвалення ЦВК СРСР «Положення про злочини державні (контрреволюційні та особливо для Союзу РСР небезпечні злочини проти порядку управління)» від 25 лютого 1927 р., а також ЦВК СРСР і РНК СРСР «Положення про військові злочини» від 27 липня 1927 р., норми яких на підставі постанови ЦВК СРСР «Про зміни основних засад кримінального законодавства СРСР і союзних республік» від 25 лютого 1927 р. включалися до республіканських Кримінальних кодексів, зокрема, й УСРР. Ці акти та низка інших змін зумовили підготовку проекту нового Кримінального кодексу (далі - КК) УСРР і в травні 1927 p. його було подано на затвердження РНК УСРР. У розробці кодексу брали участь представники наркоматів юстиції, внутрішніх справ, робочо-селянські інспекції та інших відомств УСРР. Президією ВУЦВК він був ухвалений 8 червня 1927 р. Згідно з постановою ВУЦВК 
«Про введення в дію Кримінального кодексу УСРР в редакції 1927 року» від 8 червня 1927 р. новий КК УСРР (пізніше - УРСР) набирав чинності з 1 липня 1927 р.

Згідно з постановою ЦВК і РНК СРСР «Про кримінальну відповідальність за випуск недоброякісної продукції та за недотримання стандартів» від 23 листопада 1929 р. на підставі ч. 2 ст. 3 основних засад кримінального законодавства Союзу PCP і союзних республік було запропоновано центральним виконавчим комітетам союзних республік передбачити в кримінальних кодексах: 1) за масовий або систематичний випуск з промислових і торговельних підприємств недоброякісних виробів - позбавлення волі на строк до 6 років або примусові роботи на строк до 1 року; 2) за недотримання обов'язкових стандартів - позбавлення волі до 2 років або примусові роботи на строк до 1 року.

Отже, злочином визнавалися не будь-які випадки випуску недоброякісної продукції, а лише найбільш небезпечні, коли вони мали масовий або систематичний характер. Визначалося й місце вчинення злочину, який розглядається, - промислове або торговельне підприємство. Урешті-решт установлювалася відповідальність за випуск не тільки недоброякісної продукції, але й продукції, що не відповідає обов'язковим стандартам.

Водночас постанова залишала відкритими питання про коло суб'єктів злочину, про критерії диференціації відповідальності за випуск недоброякісної або нестандартної продукції та інші [4, с. 6]. Незважаючи на ці прогалини, на думку В.Я. Тація, зазначена постанова вперше досить чітко сформулювала поняття злочину, яке лягло в основу подальшого законодавства про кримінальну відповідальність за випуск недоброякісної продукції [4, с. 5-9].

Згідно зі спільною постановою ЦВК і РНК СРСР «Про відповідальність за випуск недоброякісної продукції» від 8 грудня 1933 р. № 84/2562 випуск недоброякісної та некомплектної продукції розглядався як «тяжкий антидержавний злочин» і було встановлено, що керуючі трестів, директори підприємств і особи адміністративно-технічного персоналу, винні у випуску недоброякісної або некомплектної продукції, притягувалися до кримінальної відповідальності із застосуванням заходів судової репресії - позбавлення волі на строк не нижче 5 років.

У зв'язку з прийняттям цієї постанови ст. 135-3 КК УРСР 1927 р. було змінено, у її ч. 1 встановлювалася відповідальність за випуск недоброякісної продукції на промисловому підприємстві, а у ч. 2 - за такий самий випуск на торговельних підприємствах. Одночасно продовжувала діяти постанова ЦВК і РНК СРСР від 23 листопада 1929 р. «Про кримінальну відповідальність за випуск недоброякісної продукції та за недотримання стандартів» [4, с. 7; 6, с. 12]. Отже, законодавець уже розрізняв: 1) випуск недоброякісної продукції на промисловому підприємстві; 2) випуск недоброякісної продукції на торговельному підприємстві; 3) випуск нестандартної продукції.

Відповідно до Конституції УРСР 1937 р. з 31 січня цього ж року республіка змінила назву на «Українську Радянську Соціалістичну Республіку» (УРСР). Згідно з Указом Президії Верховної Ради СРСР «Про відповідальність за випуск недоброякісної або некомплектної продукції та за недотримання обов'язкових стандартів підприємствами» від 10 липня 1940 р. було встановлено, що випуск недоброякіс- 
ної або некомплектної промислової продукції та випуск продукції з порушенням обов'язкових стандартів був протидержавним злочином, рівносильним шкідництву, за що директорів, головних інженерів і начальників відділів технічного контролю промислових підприємств віддавали до суду та за вироком суду піддавали тюремному ув'язненню строком від 5 до 8 років.

На відміну від законодавства, що діяло раніше, цей акт установлював однакову кримінальну відповідальність за випуск недоброякісної промислової продукції та за випуск некомплектної або нестандартної продукції. В цьому Указі закріплювалися заходи відповідальності не за виробництво бракованої продукції, а за її випуск, причому не на будь-якому, а лише на промисловому підприємстві. У зв'язку з виданням зазначеного акту до ст. 135-3 КК УРСР було внесено відповідні зміни. Оскільки в ньому не містилося ніяких роз'яснень щодо відповідальності за випуск недоброякісної продукції на торговельних підприємствах і не було вказівок щодо скасування спільної постанови ЦВК і РНК СРСР «Про кримінальну відповідальність за випуск недоброякісної продукції і за недотримання стандартів» від 23 листопада 1929 р., остання продовжувала діяти.

Такі суворі заходи взагалі можна визнати обгрунтованими: вони сприяли зміцненню дисципліни в народному господарстві, особливо в роки Великої Вітчизняної війни, коли якість продукції промисловості, зокрема оборонної, мала для країни вирішальне значення [2, с. 22-23].

Стаття 135-3 КК УРСР 1927 р. у редакції Указу Президії Верховної Ради УРСР від 15 березня 1941 р. передбачала кримінальну відповідальність за випуск недоброякісної або некомплектної промислової продукції та за випуск продукції з порушенням обов'язкових стандартів, що був протидержавним злочином, рівнозначним шкідництву, директори, головні інженери і начальники відділів технічного контролю промислових підприємств. Враховуючи, що ця стаття перебувала у Розділі V «Господарські злочини» КК УРСР 1927 р., об’єктом цього злочину було народне господарство. Зважаючи, що у диспозиції ч. 1 ст. 135-3 КК УРСР 1927 р. було зазначено, що цей злочин був протидержавним злочином, рівнозначним шкідництву, то додатковим обов'язковим об'єктом цього злочину були основи народної влади та радянського ладу. Предметом цього злочину були: 1) недоброякісна промислова продукція або 2) некомплектна промислова продукція або 3) продукція, випущена з порушенням обов'язкових стандартів. Об'єктивна сторона досліджуваного злочину полягала у суспільно небезпечному діянні у формі дії у вигляді: 1) випуску недоброякісної або некомплектної промислової продукції чи 2) випуску продукції з порушенням обов'язкових стандартів. Також у диспозиції ч. 1 ст. 135-3 КК УРСР 1927 р. було зазначено, що цей злочин був протидержавним злочином, рівнозначним шкідництву. Суб'єктом розглядуваного злочину були: 1) директори промислових підприємств або 2) головні інженери промислових підприємств чи 3) начальники відділів технічного контролю промислових підприємств. Форма вини як обов'язкової ознаки суб'єктивної сторони злочину у вказаній вище нормі не визначена.

У ч. 2 ст. 135-3 КК УРСР 1927 р. була передбачена кримінальна відповідальність за масовий або систематичний випуск із торгових підприємств недоброякісної продукції. Об'єктом цього злочину було народне господарство. Предметом цього 
злочину була недоброякісна продукція. Об'єктивна сторона досліджуваного злочину полягала у суспільно небезпечному діянні у формі дії у вигляді 1) масового або 2) систематичного випуску предметів цього злочину з торгових підприємств. Отже, у диспозиції ч. 1 ст. 135-3 КК УРСР 1927 р. було визначено місце цього злочину торгові підприємства. Суб'єкт злочину та форма вини як обов'язкової ознаки суб'єктивної сторони розглядуваного злочину у вказаній вище нормі не були визначені.

Санкція ч. 1 ст. 135-3 КК УРСР 1927 р. безальтернативно передбачала самостійний судово-виправний захід соціального захисту - тюремне ув'язнення на строк від 5 до 8 років. Санкція ч. 2 ст. 135-3 КК УРСР 1927 р. передбачала покарання у виді: 1) позбавлення волі на строк до 5 років або 2) виправно-трудові роботи. Згідно з приміткою 3 до ст. 21 КК УРСР 1927 р. ув’язнення у тюрму як вид позбавлення волі мали право визначати щодо осіб, засуджених за найбільш небезпечні злочини, Верховний суд Союзу РСР, Верховний суд УРСР, обласні суди, залізничні та водно-транспортні суди і військові трибунали (в редакції 20 жовтня 1937 р.). Отже, злочини, передбачені ч. ч. 1, 2 ст. 135-3 КК УРСР 1927 р., були найбільш небезпечними, але злочин, передбачений ч. 1 ст. 135-3 КК УРСР 1927 р., був більш тяжким та суспільно небезпечним, ніж злочин, передбачений ч. 2 цієї статті. Хоча в інших статтях КК УРСР 1927 р. за загальним правилом кваліфіковані склади злочинів (кваліфікуючі (обтяжуючі) ознаки (обставини) містяться у більших (наступних) частинах, ніж ч. 1 відповідної статті. Тому злочин, передбачений ч. 2 ст. 135-3 КК УРСР 1927 р., не є кваліфікованим (з обтяжуючими ознаками) суспільно небезпечного діяння, передбаченого ч. 1 цієї статті. Причому, відповідно до ч. 1 ст. 27 КК УРСР 1927 р. позбавлення волі на строк від 3 до 10 років призначалося у виправно-трудових таборах у далеких місцевостях Союзу РСР. Строк виправно-трудових робіт, зокрема, у санкції ч. 2 ст. 135-3 КК УРСР 1927 р., не був визначений. Проте, згідно з ч. 1 ст. 28 КК УРСР 1927 р. виправно-трудові роботи без позбавлення волі призначалися на строк від одного дня до одного року і поділялися на: а) роботу за фахом, коли засуджений і надалі працював за своєю професією, б) роботу некваліфікованої фізичної праці.

Аналіз диспозицій і санкцій ч. 1 та ч. 2 ст. 135-3 КК УРСР 1927 р. свідчить, що в них розміщені окремі різні склади злочинів. Склади злочинів, передбачені ч. 1 та ч. 2 ст. 135-3 КК УРСР 1927 р., відрізняються між собою за певними ознаками. Зокрема, у ч. 1 ст. 135-3 КК УРСР 1927 р. визначений спеціальний суб'єкт злочину, а у ч. 2 - така вказівка відсутня. Крім того, відмінність між цими нормами і в особливостях характеристик предметів та ознак об’єктивних сторін цих злочинів.

Висновки. Таким чином, у результаті здійснення історично-правового дослідження розвитку кримінальної відповідальності за умисне введення в обіг на ринку України (випуск на ринок України) небезпечної продукції у вітчизняному кримінальному законодавстві 1927-1960 p.p. встановлено, що цей період характеризувався встановленням кримінальної відповідальності за випуск недоброякісної та некомплектної або нестандартної продукції у ст. 135-3 КК УСРР 1927 р. (пізніше УРСР). У зв'язку з прийняттям спільної постанови ЦВК і РНК СРСР «Про відповідальність за випуск недоброякісної продукції» від 8 грудня 1933 р. № 84/2562 у ч. 1 ст. 135-3 КК УРСР 1927 р. встановлювалася відповідальність за випуск недо- 
броякісної продукції на промисловому підприємстві, а у ч. 2 - за такий самий випуск на торговельних підприємствах.

Стаття 135-3 КК УРСР 1927 р. у редакції Указу Президії Верховної Ради УРСР від 15 березня 1941 р. передбачала кримінальну відповідальність за випуск недоброякісної або некомплектної промислової продукції та за випуск продукції з порушенням обов'язкових стандартів, що був протидержавним злочином, рівнозначним шкідництву, директори, головні інженери і начальники відділів технічного контролю промислових підприємств. У цьому аспекті позитивним, що можна запозичити у чинний КК, є те, що така більш широка норма є більш обгрунтованою порівняно з сучасною редакцією ст. 227 з точки зору кримінально-правової охорони прав споживачів. Оскільки ця охорона здійснювалася не лише від небезпечної, але й від недоброякісної продукції, яка включає в себе останню. Аналіз визначеної проблеми є перспективним для подальших наукових досліджень та запозичення позитивного історичного досвіду щодо розглядуваного злочину.

\section{Jimepamypa}

1. История советского уголовного права / Герцензон А.А., Грингауз Ш.С., Дурманов Н.Д., Исаев М.М. и др. Москва : Юрид. изд-во МЮ СССР, 1948. 466 с.

2. Готін О.М. Кримінальна відповідальність за випуск або реалізацію недоброякісної продукції в умовах ринкової економіки (проблеми теорії та практики) : дис. ... канд. юрид. наук. Луганськ : Луганська академія внутрішніх справ МВС імені 10-річчя незалежності України, 2003. 214 с.

3. Борьба с преступностью в Украинской ССР / автор очерка и составитель документов профессор П.П. Михайленко. Т. 2 (1926-1967 г.г.). Киев : КВШ МООП СССР, 1967. 952 с.

4. Таций В.Я. Уголовная ответственность за выпуск недоброкачественной промышленной продукции. Харьков : Вища школа, $1981.81 \mathrm{c}$.

5. Терлюк І.Я. Огляд історії кримінального права України : навчальний посібник. Львів : Ліга-Прес, 2007.92 с.

6. Утевский Б.С. Уголовная ответственность за выпуск недоброкачественной, некомплектной и нестандартной продукции. Москва : Госюриздат, 1955.129 с.

\section{Анотація}

Сокур T. A. Історія розвитку кримінальної відповідальності за умисне введення в обіг на ринку України (випуск на ринок України) небезпечної продукції у вітчизняному кримінальному законодавстві 1927-1960 років. - Стаття.

У статті досліджується проблема історії розвитку кримінальної відповідальності за умисне введення в обіг на ринку України (випуск на ринок України) небезпечної продукції у вітчизняному кримінальному законодавстві 1927-1960 p.p. Вирішення цієї проблеми надає змогу глибше зрозуміти правову природу цього суспільно небезпечного діяння, його ознаки, з'ясувати основні тенденції його розвитку, здійснити порівняльний аналіз і зробити висновки щодо можливого позитивного досвіду, для запозичення останнього у чинний КК.

Метою статті є здійснення історично-правового дослідження розвитку кримінальної відповідальності за умисне введення в обіг на ринку України (випуск на ринок України) небезпечної продукції у вітчизняному кримінальному законодавстві 1927-1960 p.p.

У зв'язку з прийняттям спільної постанови ЦВК і РНК СРСР «Про відповідальність за випуск недоброякісної продукції» від 8 грудня 1933 р. № 84/2562 у ч. 1 ст. 135-3 КК УРСР 1927 р. встановлювалася відповідальність за випуск недоброякісної продукції на промисловому підприємстві, а у ч. 2 - за такий самий випуск на торговельних підприємствах. Стаття 135-3 КК УРСР 1927 р. у редакції Указу Президії Верховної Ради УРСР від 15 березня 1941 р. передбачала кримінальну відповідальність за випуск недоброякісної або некомплектної промислової продукції та за випуск продукції з порушенням обов'язкових стандартів, що був протидержавним злочином, рівнозначним шкідництву, директори, головні інженери і начальники відділів технічного контролю промислових підприємств.

У результаті здійснення цього дослідження встановлено, що цей період характеризувався встановленням кримінальної відповідальності за випуск недоброякісної продукції у ст. 135-3 КК УСРР 1927 
p. (пізніше - КК УРСР). У цьому аспекті позитивним досвідом, що можна запозичити у чинний КК $€$ те, що така більш широка норма є більш обгрунтованою порівняно з сучасною редакцією ст. 227 КК 3 точки зору кримінально-правової охорони прав споживачів. Оскільки ця охорона здійснювалася не лише від небезпечної, але й від недоброякісної продукції, яка включає в себе останню.

Ключові слова: історично-правове дослідження, права споживачів, недоброякісна продукція, промислове підприємство, торговельне підприємство.

\section{Summary}

Sokur T. A. History of the development of criminal liability for the deliberate introduction into the market of Ukraine (release to the market of Ukraine) of dangerous products in domestic criminal legislation of 1927-1960. - Article.

The article explores the problem of the history of criminal responsibility for the deliberate introduction into the market of Ukraine (release to the market of Ukraine) of dangerous products in the domestic criminal legislation of $1927-1960$.

The purpose of the article is to carry out a historical and legal study of the development of criminal liability for the deliberate introduction into the market of Ukraine (release on the market of Ukraine) of dangerous products in domestic criminal legislation of 1927-1960.

The Central Executive Committee and the Council of People's Commissars of the Union of Soviet Socialist Republics adopted a joint resolution "On responsibility for the production of defective products" of December 8, 1933 No. 84/2562. In this regard, in part 1 of Article 135-3 of the Criminal Code of the Ukrainian Soviet Socialist Republic in 1927 mounted responsible for production of substandard products in an industrial plant, and in part 2 - for the same output on commercial enterprises.

Article 135-3 of the Criminal Code of the Ukrainian Soviet Socialist Republic of 1927, in the wording of the Decree of the Presidium of the Verkhovna Rada of the Ukrainian Soviet Socialist Republic of March 15, 1941, provided for criminal liability for the production of defective or incomplete industrial products, and for the release of production from the standard products state crime, tantamount to harm, directors, chief engineers and heads of departments of technical control of industrial enterprises.

As a result of this study, it was established that this period was characterized by the establishment of criminal liability for the production of defective products in Article 135-3 of the Criminal Code of the Ukrainian Socialist Soviet Republic of 1927 (later - the Criminal Code of the Ukrainian Soviet Socialist Republic). In this respect, the positive experience that can be drawn from the current Criminal Code of Ukraine is that such a broader standard is more grounded than the current wording of Article 227 of the Criminal Code of Ukraine in terms of criminal protection of consumer rights. As this protection was carried out not only from dangerous but also from defective products, which includes the latter.

Key words: historical and legal research, consumer rights, substandard products, industrial enterprise, commercial enterprise. 